Original Research

\title{
Pemberdayaan Ekonomi Masyarakat disekitar Obyek Wisata Taman Nasional Sebangau Kelurahan Kereng Bangkirai Kota Palangka Raya
}

\author{
Lia Sabtuti ${ }^{1,{ }^{*}}$, Yunikewaty $^{2}$, Tresia Kristiana ${ }^{2}$ \\ ${ }^{1}$ Biro Protokol dan Komunikasi Publik, Sekretariat Daerah Provinsi Kalimantan Tengah \\ 2 Program Studi Magister Sains Manajemen Program Pascasarjana Universitas Palangka Raya Tunjung Nyaho, Jl. Yos Sudarso \\ Palangka Raya, Indonesia 73111 \\ * Korespondensi: Lia Sabtuti (Email: lia.sabtuti@gmail.com)
}

\begin{abstract}
This study aims to examine the economic empowerment program to villagers around Sebangau National Park, Kereng Bangkirai Sub district, Palangka Raya City as well as economic advantages the gain. We also proposed strategies to improve community economic empowerment around the tourist attraction in the park. A qualitative research type with inductive approach was used to analyze data collected from government, tourism organizers, visitors and the community. The results show the economic empowerment of the community around the National Park has been going well. Items provided by the villagers around Kereng Bangkirai jetty, among others are, traditional boat attraction, household handicraft or products such as purun hat, traditional beverages, traditional food and dried fish, photo booths, and other community activities under the supervision of local social office. The promotion of tourist attraction and tourism products were done through many social media platforms. Villagers who involved in tourism attractions or providing service or unique goods earned varied incomes, depending on types of service or goods the offered. The amount of money they earn, however, still below the regional minimum wage in Central Kalimantan, although still meet their daily needs. The further economic empowerment can be achieved by improving human resources through skill training for villagers, providing them with knowledge to attract more visitors and boosting local potential. Enhancing local institution who act as the main actor in the tourism management of Sebangau National Park is also urgent to do.
\end{abstract}

\section{Keywords}

Sebangau National Park, tourism, economic empowerment, strategy, villagers

\section{PENDAhUluAN}

Berkembangnya sektor pariwisata juga diikuti dengan pertumbuhan pada sektor pertanian, perkebunan, peternakan, perikanan dan kerajinan rakyat sehingga mampu menyerap tenaga kerja dari masyarakat lokal setempat. Perlu diakui bahwa sumbangan sektor pariwisata terhadap perolehan devisa dan terbukanya lapangan kerja secara makro cukup signifikan. Sumbangan pariwisata yang secara signifikan pada perkembangan ekonomi suatu negara atau daerah tampak dalam bentuk perluasan peluang kerja, peningkatan pendapatan (devisa) dan pemerataan pembangunan spasial (Damanik et al., 2018)

Kalimantan Tengah merupakan salah satu provinsi yang terletak dan sekaligus menjadi provinsi yang paling luas di pulau Kalimantan. Secara geografis Kalimantan Tengah berbatasan langsung dengan Laut Jawa di bagian selatan, serta diapit oleh Kalimantan Timur dan Kalimantan Barat. Provinsi Kalimantan Tengah memilki luas wilayah 157.983 $\mathrm{km}^{2}$ mencakup 13 Kabupaten dan 1 Kota dengan 85 kecamatan, 101 kelurahan dan 1.340 desa. Letaknya yang strategis membuat provinsi ini kaya akan keanekaragaman hayati dan alam, sehingga menjadikannya sebagai destinasi wisata yang menarik untuk dikunjungi.

Taman Nasional Sebangau Kelurahan Kereng Bangkirai merupakan salah satu kawasan pelestarian rawa gambut terbesar di Indonesia dengan luas 542.141 ha sesuai dengan SK Menteri Kehutanan Nomor: 529/MenhutII/2012 tanggal 25 September 2012 dan berada di antara Sungai Sebangau dan Sungai Katingan. Secara administratif, Taman Nasional Sebangau terletak di Kabupaten Katingan, Kabupaten Pulang Pisau dan Kota Palangka Raya di Provinsi Kalimantan Tengah. Taman Nasional Sebangau mempunyai fungsi pokok sesuai 
Undang-undang Nomor 5 Tahun 1990 tentang Konservasi Sumber daya Alam Hayati dan Ekosistem yaitu sebagai perlindungan sistem penyangga kehidupan, pengawetan keanekaragaman tumbuhan dan satwa beserta ekosistemnya serta pemanfaatan secara lestari sumber daya alam hayati dan ekosistemnya. Terdapat tiga destinasi wisata yang berpotensi untuk dikembangkan di daerah tersebut, antara lain: 1) Sungai Koran di Kota Palangka Raya, 2) Resort Mangkok di Kabupaten Pulang Pisau, dan 3) Danau Punggualas di Kabupaten Katingan.

Taman Nasional Sebangau Kelurahan Kereng Bangkirai merupakan warisan dunia yang memiliki keanekaragaman hayati baik segi hutan rawa gambut, fauna dan flora serta sebagai penghasil oksigen yang dibutuhkan dunia. TNS, Kelurahan Kereng Bangkirai wilayah Palangka Raya merupakan pengelolaan Balai Taman Nasional Sebangau wilayah I dibawah kepala SPTN I dan terbagi menjadi daerah resort Sebangau Hulu dan resort Habaring Hurung. Objek pariwisata di Taman Nasional Sebangau, Kelurahan Kereng Bangkirai menawarkan kegiatan wisata seperti berkemah, penelusuran hutan, penelusuran gua, pengamatan kehidupan liar, menyelam, snorkeling, kano/ bersampan, selancar, arung jeram, memancing, canopy trail, outbound training, snapshot film dan kegiatan penelitian menggunakan kawasan.

Pengelolaan kawasan Taman Nasional Sebangau Kelurahan Kereng Bangkirai mulai mengalami pergeseran dari pola penguatan perlindungan menjadi pola pemanfaatan untuk kesejahteraan masyarakat. Hal ini terlihat dari upaya pihak balai Taman Nasional Sebangau, Kelurahan Kereng Bangkirai secara kolaboratif mengadakan kegiatan pemberdayaan masyarakat. Lokasi pemilihan pemberdayaan masyarakat yaitu pada Kelurahan Kereng Bangkirai dikarenakan secara administratif Kelurahan Kereng Bangkirai berbatasan langsung dengan Taman Nasional Sebangau. Selain itu, masyakarat setempat memiliki interaksi yang cukup tinggi dengan Taman Nasional Sebangau Kelurahan Kereng Bangkirai (Terry et al., 2020). keterlibatan dan peran serta masyarakat Kelurahan Kereng Bangkirai dalam upaya pengelolaan Taman Nasional Sebangau mutlak sangat diperlukan. Untuk mencapai arah sasaran tersebut, maka peningkatan kesejahteraan dan pembinaan terhadap masyarakat sekitar menjadi kunci keberhasilan. Pola kemitraan serta bantuan kepada masyarakat sekitar sebagai penyangga kawasan Taman Nasional Sebangau Kelurahan Kereng Bangkirai akan terus dikembangkan. Karena dengan peningkatan kesejahteraan dan kesadaran masyarakat akan pentingnya kawasan Taman Nasional Sebangau Kelurahan Kereng Bangkirai menjadi outcome yang diharapkan, sehingga ke depan pengelolaan Taman Nasional Sebangau menjadi lebih baik dan sejalan dengan kesejahteraan masyarakat.

Keberadaan obyek wisata Taman Nasional Sebangau telah memunculkan obyek wisata lainnya antara lain dermaga Kereng Bangkirai, yang pada awalnya tempat tersebut dimanfaatkan sebagai tempat transit pengunjung sebelum memasuki wilayah Taman Nasional Sebangau serta menjadi tempat bagi para atlet dayung untuk berlatih dan juga merupakan tempat dilaksanakannya kejuaraan dayung di Kalimantan Tengah. Di wilayah kota Palangka Raya, dermaga Kereng Bangkirai merupakan salah satu pintu gerbang atau akses bagi pengunjung menuju Taman Nasional Sebangau dengan menggunakan jasa transportasi getek/perahu mesin.

Melalui Balai Taman Nasional Sebangau dibentuklah kelompok pemberdayaan masyarakat di Kelurahan Kereng Bangkirai diantaranya kelompok nelayan, kelompok perahu getek, kelompok pemandu wisata, serta kelompok produksi rumah tangga. Keberadaan kelompok perahu getek turut memberikan kontribusi terhadap peningkatan jumlah wisatawan mancanegara maupun lokal khususnya karena banyak yang berkunjung untuk sekedar menikmati keindahan kawasan wisata melalui jasa susur sungai yang ditawarkan. Adapun angkutan air yang ada di dermaga Kereng Bangkirai antara lain perahu/getek, bebek mesin, bebek gowes, kapal susur sungai atau yang biasa disebut lanting terapung yang dilengkapi dengan jajanan makanan/minuman di dalamnya. Sedangkan kelompok lainnya yaitu pemandu wisata/tour guide, dimana pihak Balai Taman Nasional Sebangau memberikan fasilitasi kursus bahasa Inggris bagi mereka disalah satu rumah warga sekitar dermaga Kereng Bangkirai.

Selain kelompok jasa seperti yang telah diuraikan di atas, juga terdapat pedagang kios kecil di sepanjang jalur dermaga Kereng Bangkirai, kelompok usaha bagi ibu-ibu rumah tangga yang sebelumnya dibentuk melalui Dinas Sosial dan Tenaga Kerja Kota Palangka Raya sejak tahun 2016 dan turut serta menambah pendapatan keluarga. Adapun produk makanan olahan yang dihasikan antara lain: keripik pisang, keripik singkong, kerupuk ikan patin serta keripik kelakai yang produksinya musiman. Disamping produk makanan olahan, juga terdapat produk anyaman dengan bahan dasar purun, yakni sejenis rumput atau gulma yang banyak tumbuh di wilayah gambut. Produk yang dihasilkan diantaranya seperti tikar dan topi.

Masih minimnya antusiasme serta keterlibatan masyarakat setempat dalam memanfaatkan kawasan obyek wisata TN Sebangau menjadi kendala yang dihadapi pemerintah daerah setempat. Menurut Damanik et al. (2018) pelibatan masyarakat merupakan kata kunci untuk mempercepat pencapaian kesejahteraan melalui pengembangan pariwisata. Kajian yang banyak dilakukan para ahli dengan jelas menyatakan bahwa hanya dengan keterlibatan masyarakat di dalam pengambilan keputusan, pelaksana dan pembagian hasil maka mereka dapat memperoleh manfaat dari pengembangan pariwisata. Oleh sebab itu, penciptaan budaya berwisata harus dilakukan secara pararel dengan pengembangan infrastruktur. Budaya berwisata diciptakan dengan cara mendorong atau memfasilitasi orang untuk lebih tertarik berwisata. Ditingkat praktik hal ini dapat dilakukan dengan cara memobilisasi kelompok masyarakat untuk memanfaatkan sumber daya di dalam kegiatan pariwisata. Bentuk konkret programnya cukup bervariasi (Damanik et al., 2018). 


\section{METODOLOGI}

Penelitian ini menggunakan tipe penelitian kualitatif dengan pendekatan induktif. Pendekatan penelitian ini dipilih karena peneliti ingin menggambarkan permasalahan yang terjadi di lapangan secara umum dengan disertai fakta dan data sehingga gambaran mengenai permasalahan yang ada menjadi valid dan layak dicari solusinya. Kemudian dari gambaran permasalahan yang ada, kemudian peneliti akan menarik kesimpulan secara khusus sehingga diperoleh suatu pembahasan yang tepat mengenai permasalahan yang diteliti.

Peneliti memfokuskan penelitian pada 2 (dua) pendekatan. Pendekatan pertama adalah pengujian processes (proses). Alat uji yang digunakan peneliti adalah dimensi pemberdayaan: Access to Information, Inclusion and Participation, Accountability, dan Local Organization Capacity (Erdiaw-Kwasie dan Acheampong, 2018). Pendekatan kedua adalah pengujian outcome (manfaat/ hasil). Pengujian Indirect Indicator of Empowerment (indikator tidak langsung pemberdayaan) dan Direct Indicator of Empowerment (indikator langsung pemberdayaan) mengacu kepada Alsop et al. (2005). Deskripsi strategi untuk meningkatkan pemberdayaan ekonomi masyarakat disekitar obyek wisata Taman Nasional Sebangau Kelurahan Kereng Bangkirai Wilayah Kota Palangka Raya dilakukan dengan mengetahui faktor pendukung dan penghambatnya.

Untuk mempermudah mengidentifikasikan sumber data, peneliti mengklasifikasikan menjadi 3 (tiga), yaitu:

1) Person, yaitu sumber data yang bisa memberikan data berupa jawaban lisan melalui wawancara atau jawaban tertulis melalui angket. Adapun informan atau responden utama dalam penelitian ini dibagi ke dalam 3 (tiga) kluster yaitu:

a. Pemerintah

- Kepala Dinas Kebudayaan dan Pariwisata Provinsi Palangka Raya/yang mewakili

- Kepala Dinas Kebudayaan dan Pariwisata Kota Palangka Raya/yang mewakili

- Kepala Balai Taman Nasional Sebangau/yang mewakili

- Kepala SPTN 1 Wilayah Kota Palangka Raya Balai TN Sebangau/Petugas penyuluh lapangan

- Lurah/Kepala Seksi Pembangunan dan Pemberdayaan Masyarakat Kelurahan Kereng Bangkirai

- Ketua RT/RW setempat

b. Pengelola Wisata

- Ketua Kelompok Sadar Wisata Kelurahan Kereng Bangkirai

- Ketua Kelompok Nelayan

- Ketua Kelompok Perahu Getek

- Ketua Kelompok Bebek Mesin
- Ketua Kelompok Bebek Gowes

- Usaha Fotobooth

- Pemandu wisata/tour guide

c. Masyarakat dan Wisatawan

- Tokoh Masyarakat

- Pedagang kios/makanan dan minuman

- Pedagang ikan asin

- Kelompok Ibu-ibu pembuat keripik

- Kelompok Ibu-ibu pembuat anyaman

2) Place, yaitu sumber data yang menyajikan tampilan berupa keadaan diam dan bergerak dan mengacu pada lokasi tertentu.

3) Paper, yaitu sumber data yang menyajikan tanda-tanda berupa huruf, angka, gambar atau simbol-simbol lain yang memiliki makna dan dapat dipahami.

Data diperoleh melalui tiga teknik, yaitu:

1. Observasi (pengamatan langsung)

Observasi adalah menyajikan gambaran realistis perilaku atau kejadian, menjawab pertanyaan, membantu mengerti perilaku manusia, dan evaluasi yaitu melakukan pengukuran terhadap aspek tertentu, melakukan umpan balik terhadap pengukuran tersebut. (Sugiyono, 2009).

2. Wawancara

Wawancara dilakukan untuk mengetahui informasi dan ide yang berkembang dalam suatu topik. Sebelum melakukan wawancara, peneliti menyiapkan instrumen penelitian berupa pertanyaan-pertanyaan tertulis untuk diajukan, dan mencatat apa yang dikemukakan informan, serta menggali informasi lain berdasarkan penjelasan informan agar lebih lengkap dan terperinci, oleh karena itu jenis wawancara yang digunakan peneliti adalah wawancara semi terstruktur. Peneliti melakukan wawancara pada bulan Oktober-November tahun 2018.

3. Dokumentasi

Dokumentasi merupakan cara pengumpulan data dengan melihat dokumen atau catatan yang berkaitan dengan substansi dan tujuan penelitian. Dokumen bisa berbentuk tulisan, gambar, atau karya-karya monumental seseorang.

\section{HASIL}

\subsection{Proses Pemberdayaan Ekonomi Masyarakat di sekitar Objek Wisata Taman Nasional Sebangau Kelurahan Kereng Bangkirai}

Proses pemberdayaan ekonomi masyarakat disekitar objek wisata tentunya didukung melalui Access to Information. Pentingnya TIK disekitar wisata Taman 
Nasional Sebangau Kelurahan Kereng Bangkirai sebagaimana hasil wawacara dengan Bapak IG selaku Ketua RT. 01 mengatakan bahwa:

"Pemanfaatan TIK dalam mempromosikan destinasi wisata maupun produk hasil usaha yang ada di sekitar obyek wisata sudah berjalan dengan baik walaupun masih belum optimal. Pelaku usaha dan pengunjung turut serta dalam mempromosikan Dermaga Kereng Bangkirai karena merupakan pintu masuk kawasan dan lokasinya berdekatan dengan Taman Nasional Sebangau" (IG, 09/02/2019).

Dari pernyataan Bapak IG bahwa penerapan TIK di bidang pariwisata bermanfaat dalam pengembangan usaha wisata masyarakat disekitar obyek wisata yang dilakukan oleh pemerintah, wisatawan, serta masyaraka sekaligus pelaku usaha akan berdampak pada peningkatan pendapatan ekonomi. Pak IGEN (Ketua RT. 01) menambahkan bahwa:

"Kondisi saat ini belum terdapat konektivitas jaringan internet (wifi) di sekitar obyek wisata. Memang dulu pernah diusulkan ke Dinas Kominfo Kota Palangka Raya, namun hingga saat ini belum ada realisasinya" (IG, 09/02/2019).

Hal ini juga di sampaikan oleh bapak IP selaku Kasi Pembangunan Dan Pemberdayaan Masyarakat Kelurahan bahwa:

"Sampai saat ini belum ada jaringan internet yang masuk kawasan destinasi wisata" (IP, 26/02/2019).

Teknologi Informatika dan Komunikasi (TIK) penting untuk pengembangan wisata Taman Nasional Sebangau Kelurahan Kereng Bangkirai hal ini karena Teknologi Informasi dan Komunikasi (TIK) sebagai bagian dari ilmu pengetahuan dan teknologi secara umum yaitu semua teknologi yang berhubungan dengan pengambilan, pengumpulan, pengolahan, penyimpanan, penyebaran, dan penyajian informasi. Pengembangan objek wisata tidak terlepas dari peranan pemerintah khususnya Dinas Kebudayaan dan Pariwisata bagi wisatawan. Peran pemerintah sangat penting dalam melindungi wisatawan dan mempertinggi dan memperkaya pengalaman dalam berwisata melalui sarana prasarana yang ada disekitar objek wisata Taman Nasional Sebangau. Temuan Penelitian relevan dengan penelitian Simamora dan Sinaga (2016) bahwa pengembangan wisata memiliki peran dan kewajiban untuk mengakomodir sarana dan prasarana di seluruh obyek wisata. Pengembangan pariwisata, selain dapat digunakan sebagai salah satu sumber pemasukan daerah juga dapat digunakan sebagai sarana melestarikan budaya dan kearifan lokal.

\subsection{Hasil Pemberdayaan Ekonomi Masyarakat di sekitar Objek Wisata Taman Nasional Sebangau Kelurahan Kereng Bangkirai}

Kegiatan pemberdayaan masyarakat yang telah dilakukan disekitar objek wisata hingga saat ini sudah berjalan dengan baik. Kegiatan yang dilakukan seperti di bidang jasa angkutan, antara lain ada pondok atau lanting terapung, bebek mesin, bebek gowes, getek serta guide/ pemandu wisata, bidang produksi rumah tangga, seperti KUBE (Kelompok Usaha Bersama Ibu-ibu), dan kelompok binaan Dinas Sosial, pedagang kios makanan dan ikan kering, pengrajin purun dan lain- lain. Selain itu Kegiatan pemberdayaan masyarakat di Dermaga Kereng Bangkirai yang pernah dilakukan oleh pihak Kelurahan Kereng Bangkirai diantaranya: program kebersihan dan penataan ruang peruntukannya untuk masyarakat sekitar Dermaga Kereng Bangkirai. Program kebersihan dilakukan melalui kerja bakti membersihkan kanal yang tertutup oleh eceng gondok pada tahun 2018 lalu dengan mengerahkan 50 orang penduduk setempat yang diupah oleh pihak Taman Nasional Sebangau.

Sebagaimana wawancara dengan Bapak ES selaku Kepala Seksi Pengembangan Dan Pemberdayaan Masyarakat Pariwisata Dan Ekonomi Kreatif (Dinas Kebudayaan Dan Pariwisata Kota Palangka Raya) mengungkapkan bahwa:

"Pada awal tahun 2017 Dinas Kebudayaan dan Pariwisata Kota Palangka Raya tidak memiliki anggaran untuk kegiatan pemberdayaan masyarakat, sedangkan pada tahun 2018 ada 2 (dua) kegiatan yaitu: Pengemasan produk olahan ikan kering, dan Edukasi kebersihan, bagi masyarakat dan wisatawan agar ikut menjaga kebersihan dengan tidak membuang sampah sembarangan, serta mengajak masyarakat untuk berkoordinasi dengan stakeholder bahwa bukan mereka saja yang memiliki kepentingan di wilayah tersebut. Sedangkan untuk tahun 2019 akan diselenggarakan kegiatan berupa pelatihan bagi pemandu ekowisata pedesaan \& perkotaan yang dananya bersumber dari Dana Alokasi Khusus (DAK) Kementerian Pariwisata melalui Disbudpar dengan mengundang beberapa nara sumber" (ES, 13/02/2019).

Bapak ES mengungkapkan bahwa Dinas Kebudayaan dan Pariwisata Kota Palangka Raya tidak memiliki anggaran untuk kegiatan pemberdayaan masyarakat pada tahun 2017 namun tahun 2018 dan 2019 beberapa akan kegiatan dilakukan. Hasil temuan berdasarkan wawancara dengan narasumber bahwa proses pemberdayaaan masyarakat menilai peran pemerintah terutama Dinas Kebudayaan dan Pariwisata Kota Palangka Raya masih kurang. Diharapkan pelaku usaha maupun masyarakat setempat diikutsertakan dalam sosialisasi maupun penataran pembentukan sikap bagaimana menerima pengunjung/tamu dengan baik. Selain itu kelompok usaha yang dibentuk Dinas Sosial juga membuat pentol ikan, dendeng ikan. Namun kelompok tersebut berjalan hanya sekitar 5-6 bulan. Namun upaya kolaborasi untuk memasarkan produk masih kurang, minimnya mitra untuk memasarkan produk olahan, 
sehingga usaha tidak bertahan lama. Hasil temuan di lapangan ada hambatan dalam pengembangan objek wisata yaitu belum maksimalnya campur tangan pemerintah dalam memberdayakan masyarakat setempat Kelurahan Kereng Bangkirai (daerah Dermaga Kereng Bangkirai). Bidang usaha pariwisata yang diusahakan oleh masyarakat disajikan pada Tabel 1, sedangkan gambaran parorama dan layanan wisata di Dermaga Kereng Bangkirai disajikan pada Gambar 1.

Peningkatan ekonomi masyarakat disekitar obyek wisata Taman Nasional Sebangau Kelurahan Kereng Bangkirai ditandai dengan adanya beberapa kegiatan yang pernah dilaksanakan berdasarkan wawancara narasumber bapak BR selaku Wakil Ketua POKDARWIS Kereng Bangkirai yang mengungkapkan bahwa:

"Kelompok yang bergerak di bidang jasa angkutan:

Pondok terapung (11 unit), Bebek mesin (12 unit), Getek (15 unit), dan Bebek gowes (40-an unit), serta guide/pemandu wisata yang ikut dengan perahu getek saat masuk kawasan TN Sebangau, Kelompok usaha produk olahan rumah tangga antara lain ada KUBE (Kelompok Usaha Bersama Ibu-ibu) yang memproduksi: keripik kelakai, keripik pisang, keripik singkong, dll dan kelompok usaha lain yang dibentuk oleh Dinas Sosial yaitu membuat pentol ikan dan dendeng ikan, Kios atau warung yang berjejer di sepanjang Dermaga

\section{Kereng Bangkirai" (BR, 09/02/2019).}

Wawancara mengenai eksistensi kelompok usaha dipaparkan oleh Ketua RT (Bapak IG) bahwa:

"Kelompok jasa angkutan masih tetap eksis hingga sekarang, walaupun pasang surutnya pengunjung tidak dapat diprediksi. KUBE hanya berjalan sekitar 5-6 bulan setelah dibentuk. Upaya kolaborasi untuk memasarkan produk masih kurang, serta terbatasnya mitra untuk memasarkan produk olahan, sehingga usaha tidak bertahan lama. Kendala lainnya yaitu waktu untuk berproduksi, karena ibu-ibu memiliki kesibukan masing-masing di rumah, dan rata-rata masih memiliki anak kecil" (IG, 09/02/2019).

Bapak IG juga mengungkapkan bahwa:

"Untuk kelompok jasa angkutan masih beroperasi bahkan ada beberapa penambahan armada, sedangkan kelompok usaha produk olahan rumah tangga mulai surut. Begitu pula dengan penganyam purun yang masih bertahan hingga sekarang hanya 2 sampai dengan 3 orang yang domisilinya berada disekitar Kelurahan Kereng Bangkirai . Sedangkan kios/warung masih banyak disepanjang Dermaga Kereng Bangkirai" (IG, 09/02/2019).

Tabel 1. Usaha bidang pariwisata serta di Kelurahan Kereng Bangkirai

\begin{tabular}{|c|c|c|c|c|c|}
\hline No & Jenis Usaha & Jumlah & Tahun & Pengelola & Tarif/Harga \\
\hline 1 & Pondok terapung & 11 unit & - & $\begin{array}{l}\text { Dikelola pribadi/masing } \\
\text {-masing }\end{array}$ & Rp10.000/orang/15 menit \\
\hline 2 & Bebek gowes & 40 unit & 2017 & $\begin{array}{l}\text { Dikelola pribadi/masing } \\
\text {-masing }\end{array}$ & Rp20.000/30 menit \\
\hline 3 & Bebek mesin & 12 unit & 2017 & $\begin{array}{l}\text { Mahriadi (Ketua } \\
\text { Kelompok Bebek } \\
\text { mesin) }\end{array}$ & Rp20.000/30 menit \\
\hline 4 & Getek & 15 unit & 2014 & $\begin{array}{l}\text { Jumadi A. Usop } \\
\text { (Nelayan/Ketua } \\
\text { Kelompok Maju } \\
\text { Mandiri) }\end{array}$ & $\begin{array}{l}\text { - Paket Batu Ampar } \\
\text { Rp150.000/5 orang/jam } \\
\text { - Paket Sungai Koran } \\
\text { Rp350.000/getek } \\
\text { - Sekitar Dermaga Rp30.000/ } \\
\text { orang }\end{array}$ \\
\hline 5 & Penganyam purun & $2-3$ orang & sejak 2009 & & $\begin{array}{l}\text { - } \text { Bakul: Rp7.500 } \\
\text { - Topi besar: Rp10.000 } \\
\text { - Topi kecil: Rp6.000-Rp7.000 }\end{array}$ \\
\hline 6 & $\begin{array}{l}\text { Pedagang kios \& } \\
\text { makanan }\end{array}$ & 18 kios & 2017 & & \\
\hline 7 & $\begin{array}{l}\text { Penjual ikan/Kios } \\
\text { ikan kering }\end{array}$ & 3 kios & $\begin{array}{l}\text { baru } \\
\text { beberapa } \\
\text { bulan }\end{array}$ & & \\
\hline 8 & Photo booth & 4 tempat & $\begin{array}{l}\text { baru } \\
\text { beberapa } \\
\text { bulan (setelah } \\
\text { hari raya) }\end{array}$ & Pribadi & Tarif Rp5.000-Rp10.000/view \\
\hline
\end{tabular}



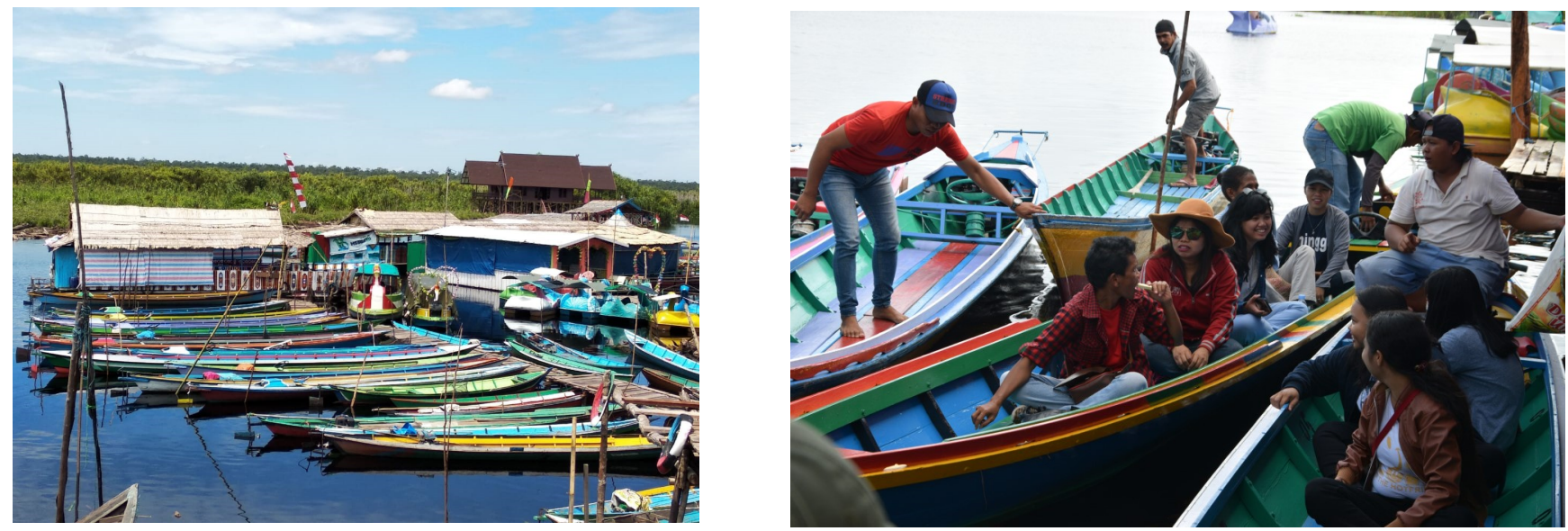

Gambar 1. Parorama dan layanan wisata di Dermaga Kereng Bangkirai

Namun kelompok usaha yang terbentuk mengalami kendala dalam proses pemberdayaan sebagaimana dipaparkan oleh narasumber bahwa masih belum maksimalnya campur tangan pemerintah dalam memberdayakan masyarakat setempat Kelurahan Kereng Bangkirai (daerah Dermaga Kereng Bangkirai).

Adapun kegiatan yang pernah dilaksanakan antara lain adalah BNF (Borneo Nature Foundation) yang melaksanakan kegiatan pendidikan lingkungan bagi anakanak sekolah dan putus sekolah di sekitar Kelurahan Kereng Bangkirai. Sedangkan penyuluh di Taman Nasional Sebangau mengadakan kursus bahasa Inggris bagi pemandu wisata/guide (namun bertahan hanya sekitar 3 bulan).

Kendala yang dihadapi warga dalam upaya meningkatkan ekonomi mereka yaitu:

1. Peran pemerintah terutama Dinas Kebudayaan dan Pariwisata Kota masih kurang. Diharapkan pelaku usaha maupun masyarakat setempat diikutsertakan dalam sosialisasi maupun penataran pembentukan sikap bagaimana menerima pengunjung/tamu dengan baik. Selain itu kurangnya pendampingan terhadap kelompok usaha produksi olahan rumah tangga oleh pihak terkait.

2. Upaya pemberdayaan masyarakat sekitar Kelurahan Kereng Bangkirai masih belum maksimal. Peran pihak kelurahan hanya sebagai back-up yang mengawasi, saran-saran dari masyarakat ditampung dan diteruskan ke dinas melalui Musyawarah Perencanaan Pembangunan.

3. Himbauan terkait sampah kepada masyarakat perlu digalakkan mengingat daerah wisata harus mencerminkan kebersihan dan keindahan.

4. Program pengawasan dan pembinaan yang telah direncanakan sudah jadi, namun pagu anggaran yang ada tidak memenuhi, sehingga tidak dapat terealisasikan. Pada dasarnya sudah tertuang melalui program di RKA, namun jika tidak disetujui/terbentur dana maka dinas hanya melakukan tugas pengawasan dan pembinaan kepada masyarakat sekitar obyek wisata. Adapun rencana strategis dari Dinas
Kebudayaan dan Pariwisata Kota Palangka Raya termuat dalam RIPKO (Rencana Induk Pengembangan Pariwisata Kota) Palangka Raya.

5. POKDARWIS (Kelompok Sadar Wisata) merupakan kelompok yang dibentuk oleh masyarakat sekitar Dermaga Kereng Bangkirai sendiri, dimana ketentuan, kebijakan, aturan yang ada bersumber dari mereka dan untuk mereka sendiri. Pihak Disbudpar Kota hanya berwenang dalam mengeluarkan SK keanggotaan Pokdarwis, mengawasi dan membina anggotanya. Yang menjadi kendala lainnya hingga saat ini yaitu seksi cendera mata belum menghasilkan cendera mata khas Palangka Raya yang bisa dijual kepada pengunjung sebagai buah tangan dan oleh - oleh ciri khas karena dinas terkait memiliki prioritas untuk program lain.

6. Perubahan tata kehidupan khususnya mata pencaharian masyarakat sekitar daerah wisata, sekarang beralih dengan memanfaatkan destinasi wisata yang ada. Artinya masyarakat sekitar dermaga sangat bergantung dengan keberadaan tempat wisata tersebut. Yang menjadi hambatan saya kira masih belum maksimalnya campur tangan pemerintah dalam memberdayakan masyarakat Kelurahan Kereng Bangkirai (khususnya daerah Dermaga Kereng Bangkirai).

7. Yang dominan dalam mempromosikan destinasi wisata adalah Dinas Kebudayaan Pariwisata Kota dan Taman Nasional Sebangau, dan juga komunitas yang dibentuk untuk membantu mempromosikan destinasi wisata, seperti Komunitas GenPI. Upaya tersebut sudah berjalan dengan baik namun perlu ikut serta masyarakat dalam memperkenalkan destinasi wisata ke khalayak umum.

8. Belum adanya pelatihan bagi pemandu wisata (guide), padahal guide sering diperlukan pengunjung khususnya turis asing.

9. Memberdayakan masyarakat bukan perkara mudah. Sebagian besar masyarakat terkadang lebih senang mendapat bantuan yang manfaatnya dapat langsung diterima tanpa harus menunggu lama. 
10. Keinginan masyarakat untuk lebih mandiri agak sulit.

11. Wujud kegiatan dari pihak Balai Taman Nasional Sebangau, Kelurahan Kereng Bangkirai diberikan melalui pelatihan, pengembangan keterampilan, pengolahan dan lain-lain yang tidak dapat langsung dirasakan hasilnya. Mungkin karena disini hasil Sumber Daya Alam (SDA) melimpah, sebagian masyarakat cenderung lebih memilih sesutau yang langsung dapat dirasakan hasilnya. Namun pihak Taman Nasional Sebangau, Kelurahan Kereng Bangkirai beruntung dapat merangkul anggota kelompok getek yang dulunya adalah para pembalak kayu. Dengan adanya usaha itu yang dulunya mereka bergantung pada sumber daya alam di hutan, sekarang sudah tidak. Merupakan suatu prestasi bagi Taman Nasional Sebangau, Kelurahan Kereng Bangkirai ketika kami bisa mencarikan alternatif mata pencaharian lain. Sedangkan mata pencaharian sebagai nelayan merupakan kearifan lokal masyarakat disekitar wilayah Taman Nasional Sebangau karena sungai disini masih bagus dan potensi ikannya juga sangat banyak.

$\mathrm{Bu}$ LI (Kepala SPTN I/Wil. Kota Palangka Raya) menambahkan bahwa:

1. Kerjasama dengan Disbudpar Provinsi Kalimantan Tengah pada tahun 2018 lalu (sumber: Dana Alokasi Khusus) berupa pembuatan sarplas, sedangkan rencana untuk tahun 2019 yaitu penambahan toilet, menara pandang, dan information center.

2. Pengembangan wisata lebih dikhususkan pada daerah Sebangau Hulu (Sungai Koran) SPTN wilayah I (Kota Palangka Raya), antara lain dengan penambahan fisik yaitu titian, toilet, pendopo, menara pandang dan sarplas/atraksi wisata., adapun sumber dananya berasal dari DAK melalui Dinas Kebudayaan dan Pariwisata Provinsi Kalimantan Tengah.

3. Penyusunan zonasi diawali dengan menentukan zona pemanfaatan, kemudian terbagi menjadi Desain tapak berupa: a) Ruang usaha, dan b) Ruang Publik. Ruang publik inilah yang ditawarkan ke pihak ketiga untuk ikut serta usaha diwilayah tersebut, usaha dibidang apa (UPJWA/Jasa, atau UPSWA/sarana).

4. Sehubungan keberadaan kelompok getek wisata, ada peraturan terbaru tentang "Kemitraan Konservasi", salah satunya dalam mengakomodir masyarakat yang ada disekitar kawasan untuk memiliki izin terkait jasa transportasi. Oleh sebab itu, kelompok ini sedang didampingi pihak TN. Sebangau agar mereka memiliki izin yang legal saat membawa turis masuk kawasan TN. Sebangau melalui dermaga Kereng Bangkirai, ditinjau dari status kawasan secara hukum, wilayah dermaga kereng bangkirai merupakan pintu masuk ke Taman Nasional Sebangau.

\subsection{Strategi Pemberdayaan Ekonomi Masyarakat di sekitar Objek Wisata Taman Nasional Sebangau Kelurahan Kereng Bangkirai}

Berdasarkan informasi Tirta S.Sos dan Lisna Yulianti, faktor penghambat pemberdayaan ekonomi masyarakat di sekitar obyek wisata TN. Sebangau adalah:

1. Tingkat kreativitas masyarakat dalam usaha budidaya dan menciptakan produk-produk masih rendah;

2. masih tingginya tingkat ketergantungan masyarakat terhadap alam;

3. Belum tertatanya sentra atau zona aktivitas dan fasilitas sekitar obyek wisata (tempat belanja dan jajanan/ makanan khas);

4. Belum optimalnya sarana informasi dan interpretasi terhadap atraksi-atraksi wisata (alam, heritage, buatan manusia);

5. Minimnya sarana dan prasarana MICE berskala besar;

6. Belum optimalnya dukungan Sapta Pesona pariwisata di Provinsi Kalimantan Tengah;

7. Belum optimalnya pemasaran pariwisata Kalimantan Tengah terutama untuk wisatawan mancanegara;

8. Belum optimalnya integrasi dan koordinasi promosi wisata se-Kalimantan Tengah.

Sedangkan yang menjadi faktor pendukung pemberdayaan ekonomi masyarakat sekitar TN. Sebangau adalah:

1. Daya dukung iklim, suasana dan banyaknya Obyek Daya Tarik Wisata yang menarik minat wisatawan;

2. Kemajuan teknologi informasi, memudahkan calon wisatawan memperoleh akses informasi terkini mengenai keunikan dan keanekaragaman destinasi pariwisata;

3. Promosi destinasi wisata oleh Pokdarwis dan masyarakat sekitar obyek wisata;

4. Adanya peran Balai Taman Nasional Sebangau berpengaruh terhadap peningkatan upaya pemberdayaan masyarakat;

5. Pemerintah Daerah melalui Dinas dan mitra terkait memberikan bantuan modal usaha agar kegiatan pemberdayaan masyarakat di sekitar Taman Nasonal Sebangau Kelurahan Kereng Bangkirai dapat berjalan;

6. Pentingnya menjaga kawasan Taman Nasional Sebangau, Kelurahan Kereng Bangkirai merupakan tujuan utama disamping memanfaatkan sumber daya alamnya;

7. Kekayaan alam yang melimpah dan keragaman budaya yang unik sehingga mampu sebagai magnet untuk mendatangkan wisatawan, sehingga berdampak bagi peningkatkan kesejahteraan masyarakat.

\section{PEMBAHASAN}

Berdasarkan hasil temuan di lapangan mengenai Proses pemberdayaan ekonomi masyarakat di sekitar objek wisata Taman Nasional Sebangau yang berbatasan dengan 
Kelurahan Kereng Bangkirai harus melibatkan semua elemen masyarakat dan pemerintah. Akses informasi memiliki peranan penting, hal ini Seiring dalam perkembangannya teknologi informasi dan komunikasi ini juga semakin membantu dan memudahkan manusia dalam berbagai sektor kehidupan. Peranan teknologi informasi dan komunikasi banyak sekali sektor kehidupan manusia yang semakin terbantu dengan adanya perkembangan teknologi informasi dan komunikasi. Bahkan sektor pariwisata pun juga terbantu dengan perkembangan teknologi dan komunikasi. Peranan teknologi informasi dan komunikasi dalam sektor pariwisata cukup besar dan penting, karena dengan adanya teknologi informasi dan komunikasi memudahkan para wisatawan untuk mengetahui lebih mudah tentang tempat-tempat wisata yang ada sekalipun didaerah terpencil sekalipun.

Teknologi informasi dan komunikasi tidak hanya memudahkan para wisatawan untuk mengetahui tempattempat wisata yang ada tetapi juga dalam perancanaan dan perjalanan liburan, contohnya seperti pemesanan tiket perjalanan, pemesanan hotel, pemilihan tempat wisata, bertransaksi. Hal-hal tersebut dapat dilakukan dengan sangat mudah dan cepat, hanya dengan mengoperasikan gadget wisatawan bisa mendapat informasi yang cepat, tepat, akurat dan mudah. Kemudahan seperti ini akan membuat wisatawan puas dan senang, tentunya juga akan menimbulkan rasa ingin kembali lagi untuk berlibur. Selain bermanfaat bagi para wisatwan juga memberikan manfaat bagi para pengusaha di bidang pariwisata untuk mempromosikan jasa atau pun produknya.

Pemberdayaan ekonomi masyarakat tidak terlepas dari perilaku partisipasi semua elemen masyarakat. Pihak yang diberdayakan adalah masyarakat sekitar TNS. Sebagaimana penelitian Jalunggono dan Destiningsih (2018) mengemukakan bahwa proses pemberdayaan ekonomi masyarakat disekitar objek wisata adalah meliputi tahap penyadaran dan pembentukan perilaku menuju perilaku sadar dan peduli sehingga merasa membutuhkan peningkatan kapasitas diri, tahap transformasi kemampuan berupa wawasan pengetahuan, kecakapan keterampilan agar terbuka wawasan dan pemberian keterampilan dasar sehingga dapat mengambil peran di dalam pembangunan, tahap peningkatan kemampuan intelektual, kecakapan keterampilan sehingga terbentuklah inisiatif dan kemampuan untuk mengantarkan pada kemandirian.

Berdasarkan temuan di lapangan bahwa sebagai bentuk perhatian Taman Nasional Sebangau dalam bersinergi dengan usaha pengembangan ekonomi masyarakat di sekitar Kawasan Konservasi, pihak Balai Taman Nasional Sebangau telah membentuk kelompok kegiatan pemberdayaan masyarakat di Kelurahan Kereng Bangkirai.. Alasan menjadikan kelurahan Kereng Bangkirai sebagai lokasi pemberdayaan masyarakat karena secara administratif kelurahan Kereng Bangkirai berbatasan langsung dengan Taman Nasional Sebangau, serta keberadaan masyarakat kelurahan tersebut memiliki interaksi yang cukup tinggi dengan Taman Nasional
Sebangau. Kegiatan pemberdayaan masyarakat yang dilakukan oleh Balai Taman Nasional Sebangau dapat meningkatkan kemandirian dan kesejahteraan masyarakat di sekitar Taman Nasional Sebangau serta masyarakat berpartisipasi aktif menjadi mitra Balai Taman Nasional Sebangau dalam pengembangan kegiatan konservasi. Kegiatan yang dilakukan sepert Bidang jasa angkutan, antara lain ada pondok terapung, bebek mesin, getek, dan Bebek gowes serta guide/pemandu wisata. Bidang produksi rumah tangga, seperti KUBE (Kelompok Usaha Bersama lbu-ibu ), dan kelompok binaan Dinas Sosial.

Perspektif bahwa Balai Taman Nasional Sebangau perlu terlibat dalam kegiatan pemberdayaan yang berkolaborasi dengan masyarakat dapat berdampak pada peningkatan kesejahteraan masyarakat yang bermukim disekitar Taman Nasional Sebangau. Dengan demikian, masyarakat tidak sampai merambah masuk ke hutan, merusak sumber daya alam yang ada demi memenuhi kebutuhan hidup keluarganya sehari-hari. Dari sudut sosial, kegiatan pariwisata akan memperluas kesempatan tenaga kerja baik dari kegiatan pembangunan sarana dan prasarana maupun dari berbagai sektor usaha yang langsung maupun yang tidak langsung berkaitan dengan kepariwisataan.

Kegiatan pemberdayaan masyarakat di wisata Taman berbasis masyarakat untuk meningkatakan ekonomi masyarakat setempat. Wisata TNS berbasis masyarakat sebagai sebuah pendekatan pemberdayaan yang melibatkan dan meletakkan masyarakat sebagai pelaku penting dalam konteks paradigma baru pembangunan yakni pembangunan yang berkelanjutan (sustainable development paradigm) pariwisata berbasis masyarakat merupakan peluang untuk menggerakkan segenap potensi dan dinamika masyarakat, guna mengimbangi peran 5 pelaku usaha pariwisata skala besar. Pariwisata berbasis masyarakat tidak berarti merupakan upaya kecil dan lokal semata, tetapi perlu diletakkan dalam konteks kerjasama masyarakat secara global

Taman Nasional Sebangau perlu terlibat dalam kegiatan pemberdayaan masyarakat melalui pembinaan partisipasi masyarakat yang bertujuan untuk:

1. Program Peningkatan Kesejahteraan Masyarakat

Keterlibatan sebagian anggota masyarakat sebagai pendamping penelitian (termasuk pemantauan) termasuk aspek hidrologi, iklim dan lahan gambut secara tidak langsung juga memberikan pendapatan pada masyarakat. Demikian pula pada kegiatan pengelolaan, akan membutuhkan keterlibatan anggota masyarakat dalam jumlah yang cukup banyak.

2. Program Peningkatan Kesadaran Masyarakat

Keterlibatan anggota masyarakat dalam berbagai kegiatan penelitian dan pengelolaan pada kawasan Taman Nasional Sebangau setidaknya menumbuhkan kesadaran akan pentingnya perlindungan kawasan Taman Nasional Sebangau. Keterlibatan tersebut dapat dimulai dari desain kegiatan (misalnya desain dam/ tabat) hingga pelaksanaan kegiatan, sehingga masyarakat juga menjadi bagian dari kegiatan 
pengeloaan Taman Nasional Sebangau. Berdasarkan hal tersebut, sejauh ini peran masyarakat sangat diperlukan dalam melindungi kawasan Taman Nasional Sebangau serta turut memberikan pengaruh terhadap peningkatan kesejahteraan masyarakat. Sehingga pada akhirnya tertanam sikap pada diri mereka bahwa dalam memenuhi kebutuhan hidup keluarganya yang sangat bergantung penuh terhadap keberadaan Taman Nasional Sebangau, tetap menjaga dan melestarikan kawasan tersebut beserta sumber daya alam yang ada di dalamnya dengan sebaik-baiknya.

Awang (2006) mengemukakan bahwa interaksi masyarakat dengan kawasan hutan Taman Nasional Sebangau, Kelurahan Kereng Bangkirai ditandai dengan pola-pola pemanfaatan potensi yang ada dalam kawasan hutan oleh warga masyarakat yang ada di sekitar kawasan Taman Nasional Sebangau, Kelurahan Kereng Bangkirai. Sejak kawasan Sebangau dieksploitasi oleh perusahaan hutan $(\mathrm{HPH})$, pola interaksi masyarakat ditandai oleh 2 model pemanfaatan yaitu: (1) pemanfaatan hasil hutan berupa kayu-kayu komersial; dan (2) pemanfaatan hasil hutan bukan kayu seperti penangkapan ikan di sungai dan danau yang ada dalam kawasan hutan, pengumpulan rotan, pengumpulan gaharu, dan juga pengumpulan gemor.

Pemanfaatan kayu merupakan sumber ekonomi yang "instan" dari sebagian besar masyarakat sekitar kawasan Sebangau. Penebangan kayu tersebut tidak dilakukan dengan cara yang sesuai dengan aturan, tidak memiliki izin dari pemerintah dan pasti tidak ada upaya-upaya untuk melakukan rehabilitasi atas sumber daya hutan yang sudah ditebang. Pemasaran kayu tersebut lebih sederhana karena sudah ada pedagang penampung tingkat desa. Permodalan diperoleh dari para pedagang yang biasanya menjadi "pemodal" bagi para penebang kayu-kayu komersial tersebut. Nilai tambah ekonomi kayu biasanya dinikmati oleh para pemodal tersebut. Sementara itu masyarakat memperoleh predikat sebagai penebang kayu haram (illegal logging), yang sesungguhnya hanya mencari penghasilan dari apa yang mereka mampu lakukan sesuai dengan peluang usaha dan kemampuan sumber daya manusia. Bagi upaya-upaya menuju pengelolaan kawasan Taman Nasional Sebangau Kelurahan Kereng Bangkirai, tindakan penebangan kayu-kayu komersial tersebut tentu saja merupakan masalah yang harus dicarikan jalan keluarnya (Awang, 2006).

Pemanfaatan hasil hutan bukan kayu yang berasal dari kawasan Taman Nasional Sebangau, Kelurahan Kereng Bangkirai sejak sebelum ada HPH juga sudah dimanfaatkan untuk memenuhi kebutuhan keluarga masyarakat yang tinggal sekitar kawasan sebangau. Selama ini masyarakat biasa mengumpulkan rotan, gemor, dan menangkap ikan dari kawasan sekitar Taman Nasional Sebangau.

Penangkapan ikan dilakukan oleh masyarakat di sungai -sungai dan danau-danau kecil yang berada di dalam kawasan Taman Nasional Sebangau, kelurahan Kereng
Bangkirai. Demikian pula halnya masyarakat mengumpulkan rotan, mengambil gemor (kulit pohon) dan getah jelutung dari kawasan sebangau. Kegelisahan masyarakat saat ini adalah apakah mereka masih tetap diperbolehkan memanfaatkan hasil hutan bukan kayu seperti rotan, gemor, getah jelutung, dan menangkap ikan, setelah kawasan sebangau ditetapkan sebagai kawasan pelestarian alam dengan bentuk kelola TNS, Kelurahan Kereng Bangkirai. Kegelisahan inilah yang menjadi masalah mendasar bagi masyarakat sekitar TNS, Kelurahan Kereng Bangkirai. Dengan demikian hal yang menjadi serius adalah segera pihak pemerintah memperjelas tata batas kawasan TNS Kelurahan Kereng Bangkirai dan meminta persetujuan dari warga masyarakat di desa-desa yang langsung berbatasan dengan kawasan TNS Kelurahan Kereng Bangkirai.

Proses pemberdayaan melalui usaha ekonomi masyarakat lainnya yang terkait dengan perairan umum dan Taman Nasional Sebangau, Kelurahan Kereng Bangkirai juga memiliki masalah karena letak geografis. Kurangnya infrastruktur dan fasilitas, prossesing pasca panen, dan lemahnya jaringan pemasaran produksi. Masalah yang dirasakan oleh pelaku usaha di sekitar TN Sebangau umumnya menyangkut masalah pemasaran hasil usaha. Seperti harga rotan yang tidak stabil, harga ikan yang sering jatuh pada saat musim ramai (Awang, 2006).

Sektor pariwisata adalah sektor yang bisa menjadi alternatif pengembangan ekonomi masyarakat. Objek wisata harus dikelola dengan baik. Pengelolaan pariwisata yang baik dan terencana akan berdampak positif bagi ekonomi, sosial dan budaya (Sembiran dan Rondonuwu, 2017).

Pemberdayaan ekonomi, diperuntukkan sebagai upaya meningkatkan kemampuan yang diperintah sebagai konsumen agar dapat berfungsi sebagai penanggung dari dampak negatif pertumbuhan, pembayar resiko salah urus, pemikul beban pembangunan, kegagalan program, dan akibat kerusakan lingkungan (Pratiwi, 2017). Dengan demikian yang dimaksud pembangunan ekonomi di objek wisata merupakan bentuk potensi untuk menguasai hajat hidup orang banyak dengan menerapkan prinsip atau azas ekonomi kerakyatan. Pembangunan ekonomi untuk masyarakat di objek wisata dapat dilakukan yakni pengembangan pemberdayaan usaha kecil (Suryatman dan Setiowati, 2016).

Proses pemberdayaan ekonomi yaitu: (a) pengembangan program tujuan wisata, menyebutkan bahwa tahap ini adalah tahap penyadaran dimana pada tahap ini dilakukan sosialisasi pembentukan desa wisata kepada masyarakat desa. Proses sosialisasi dilakukan oleh para tokoh desa melalui rapat-rapat desa dengan memberikan pemahaman kepada masyarakat tentang pembentukan desa wisata di lingkungan tempat tinggal mereka (Andayan et al., 2017). (b) pengembangan program pemasaran pariwisata, dalam hal ini adalah kegiatan pengenalan dan promosi, hal ini sesuai dengan penelitian yang dilakukan Sukma (2018) yang menyatakan bahwa 
secara simultan promosi berpengaruh positif dan signifikan terhadap jumlah pengunjung pada objek wisata, hal ini dikarenakan semakin sering melakukan promosi dengan fasilitas baru yang ditawarkan seseorang akan tertarik berkunjung ke tempat tersebut, dan (c) program pengembangan kemitraan, untuk pengembangan ini perlu dilakukan kerjasama atau kemitraan melalui pendekatan dengan organisasi pariwisata yang ada yang terdiri dari pemerintah, swasta, dan masyarakat dan pihak-pihak terkait yang diharapkan dapat mendukung kelanjutan pembangunan pariwisata di daerah itu (Kurniawan, 2013).

Pebriani et al. (2017) menyatakan bahwa pengembangan wisata dengan kemitraan antara pemerintah, swasta dan masyarakat memiliki dampak positif yang dirasakan dari adanya kemitraan tersebut yaitu memberikan manfaat dalam lapangan pekerjaan dengan memperdayakan masyarakat sekitar dan nantinya masyarakat akan mampu meningkatkan kesejahteraan serta perekonomiannya. Selain itu kondisi ini juga tentunya dapat membantu pemerintah dalam menurunkan jumlah kemiskinan dan pengangguran di desa. Barreto dan Giantari (2015) menyatakan bahwa pengembangan kepariwisataan pada suatu daerah tujuan wisata akan selalu diperhitungkan dengan keuntungan dan manfaat bagi masyarakat banyak.

Proses pemberdayaan masyarakat lokal memanfaatkan berbagai ruang sosial yang dimiliki masyarakat setempat. Ruang sosial tersebut merupakan suatu arena dalam proses kontruksi sosial. Adapun ruang-ruang sosial yang dimanfaatkan sebagai arena sosial dalam mengkonstruksi atau memberdayakan masyarakat seperti pertemuan desa, aktifitas keagamaan dan pertemuan organisasi antar masyarakat seperti karang taruna, PKK dan lembaga pendidikan. Dengan demikian berbagai potensi kelembagaan merupakan ruang sosial yang strategis bagi proses pemberdayaan masyarakat baik dalam kaitannya dengan pelestarian lingkungan khususnya pelestarian terumbu karang, pengintegrasian sosial/keharmonisan hubungan antar anggota masyarakat, penguatan kehidupan ekonomi dan pengembangan pariwisata.

Masruroh dan Nurhayati (2016) menyatakan bahwa pengembangan destinasi pariwisata yang berkelanjutan, dapat dilakukan melalui 1) peningkatan konsolidasi akses transportasi terutama antar pemerintah daerah perbatasan yang tergabung dalam kunci bersama, 2) perbaikan dan peningkatan kualitas jaringan prasarana dan sarana pendukung pariwisata serta meningkatkan kualitas dan standar pelayanan minimum pariwisata, 3) penataan dan diversifikasi daya tarik wisata alam, wisata budaya dan wisata buatan termasuk event dan olah raga, 4) pengembangan destinasi pariwisata di daerah terdepan, terluar dan wilayah perbatasan, 5) pengembangan agropolitan yang merupakan konsepsi pengembangan wilayah berbasis pedesaan tempat sumber daya pertanian dengan cara mengadaptasikan elemen-elemen pertanian modern dengan meningkatkan akses jaringan ekonomi (pariwisata) regional yang lebih luas, 6) pengembangan daya tarik wisata dan inovasi produk yang berbasis lingkungan, 7) peningkatan koordinasi lintas sektor dan lintas stakeholder pengembangan daya tarik wisata, 8) penataan kebijakan dana manajemen daya tarik wisata dan produk pariwisata, 9) pemanfaatan media cetak, elektronik, dan public figure dan media kesenian tradisional, 10) pengamanan dan kenyamanan oleh masyarakat di destinasi, 10) peningkatan efektivitas pengelolaan destinasi pariwisata melalui peningkatan koordinasi dan keterpaduan pembangunan pariwisata dan Destination Management Organization (DMO) dan 11 pengembangan destinasi pariwisata dengan meningkatkan apresiasi seni dan budaya lokal.

\section{KETERBATASAN PENELITIAN}

Penelitian ini hanya terbatas pada pemberdayaan ekonomi masyarakat disekitar obyek wisata Taman Nasional Sebangau Kelurahan Kereng Bangkirai, sehingga diharapkan penelitian yang akan datang meneliti proses, hasil dan strategi pemberdayaan ekonomi masyarakat secara menyeluruh di 3 (tiga) wilayah sekitar Obyek Wisata Taman Nasional Sebangau yaitu: Kota Palangka Raya, Kabupaten Pulang Pisau dan Kabupaten Katingan.

\section{KESIMPULAN DAN REKOMENDASI}

Berdasarkan hasil penelitian dan pembahasan tentang pemberdayaan ekonomi masyarakat disekitar obyek wisata Taman Nasional Sebangau Kelurahan Kereng Bangkirai, maka dapat disimpulkan bahwa Kegiatan pemberdayaan ekonomi masyarakat disekitar objek wisata Taman Nasional Sebangau Kelurahan Kereng Bangkirai, hingga saat ini sudah berjalan dengan baik. Kegiatan yang dilakukan antara lain bergerak dibidang jasa angkutan: pondok/ lanting terapung, bebek mesin, bebek gowes, getek serta guide/pemandu wisata, bidang produksi rumah tangga, sempat terbentuk KUBE (Kelompok Usaha Bersama Ibuibu), dan kelompok binaan Dinas Sosial, pedagang kios makanan dan ikan kering, pengrajin purun, usaha fotobooth dan lain sebagainya. Pemanfaatan Teknologi Informasi dan Komunikasi dalam mempromosikan destinasi wisata maupun produk hasil atau outcome usaha disekitar obyek wisata sudah berjalan dengan baik. Melalui Dinas Kebudayaan Pariwisata Kota Palangka Raya, Disbudpar Provinsi Kalteng, Balai Taman Nasional Sebangau, serta komunitas seperti GenPI sangat berperan dalam mempromosikan destinasi wisata. Upaya tersebut sudah berjalan dengan baik namun perlu peran serta masyarakat dalam memperkenalkan destinasi wisata ke khalayak umum.

Berdasarkan pembahasan hasil penelitian dan kesimpulan yang sudah dipaparkan sebelumnya, beberapa 
rekomendasi yang dapat menjadi masukan bagi pihakpihak terkait dalam pemberdayaan ekonomi masyarakat disekitar obyek wisata Taman Nasional Sebangau Kelurahan Kereng Bangkirai sebagai berikut:

1. Pemerintah melalui Dinas Kebudayaan dan Pariwisata serta dinas terkait lainnya dan Balai Taman Nasional Sebangau perlu memberikan dorongan dan semangat kepada masyarakat agar memiliki motivasi dalam mengembangkan potensi daerah masing-masing, melalui:

a) Peningkatan kapasitas anggota maupun kelompok melalui kegiatan pelatihan, seminar dan diseminasi yang difasilitasi oleh pihak Balai Taman Nasional, dinas terkait, Kelurahan setempat, maupun pihakpihak lain yang berkepentingan.

b) Penyadartahuan kepada masyarakat bahwa banyak sektor lain yang bisa dikembangkan dengan memanfaatkan SDA secara bijak yang ada di sekitar kawasan Taman Nasional Sebangau, seperti usaha kelontong, produk kerajinan tangan/souvenir khas, dan lain sebagainya.

c) Kegiatan studi banding dengan melibatkan masyarakat yang bergerak pada bidang pramu wisata ke daerah lain yang kegiatan pemberdayaannya jauh lebih maju dan berhasil dan ada tindak lanjut dari kegiatan tersebut.

d) Pemerintah dapat mengadakan sosialisasi atau pendampingan secara langsung ke daerah obyek wisata agar tercapai keberhasilan pemberdayaan masyarakat melalui kegiatan produksi, distribusi dan konsumsi masyarakat.

e) Kebijakan yang berkaitan dengan pengelolaan parkir yang lebih baik tanpa merugikan pihak tertentu serta Perjanjian bagi hasil atas tiket masuk wisata, seharusnya dibuat dalam atau dituangkan dalam Peraturan Walikota agar lebih legal serta penerapan sistem tiket atau antrian pengunjung untuk menaiki angkutan dirasa perlu agar lebih tertib.

f) Promosi panorma alam dan produk-produk kerajinan warga lokal belum dilakukan maksimal, baik menggunakan media konvensional seperti spanduk dan poster maupun menggunakan media sosial yang sepeti Instragram, Facebook, Twitter, maupun Youtube.

2. Pentingnya partisipasi masyarakat disekitar Taman Nasional Sebangau Kelurahan Kereng Bangkirai dalam mengembangkan obyek wisata, mendapatkan kesempatan kerja dengan mengembangkan produkproduk unggulan akan turut berkontribusi dalam meningkatkan perekonomian rumah tangga.

3. Diharapkan peneliti akan datang agar melakukan penelitian yang lebih lengkap dan mendalam serta mampu menggali potensi yang dimiliki oleh daerah sehingga suatu saat dapat melakukan strategi pemberdayaan guna mencapai keberhasilan yang maksimal.

\section{DAFTAR PUSTAKA}

Alsop, R., Bertelsen, M. and Holland, J., 2005. Empowerment in practice: From analysis to implementation. The World Bank.

Andayani, A. A. I., Martono, E., and Muhamad, M. 2017. Pemberdayaan Masyarakat Melalui Pengembangan Desa Wisata dan Implikasinya Terhadap Ketahanan Sosial Budaya Wilayah (Studi Di Desa Wisata Penglipuran Bali). Jurnal Ketahanan Nasional, 23(1), 116.

Awang, S. A., 2006. Perencanaan Kolaborasi Taman Nasional Sebangau, Analisis, Konsep dan Kegiatan. WWF Kalimantan Tengah. Diakses dari: https://TNS, KelurahanKerengBangkiraiSebangau.files.wordpress.co m/2018/03/san-afri-awang 2006-colaborationmanagement-plan-of-sebangau-np.pdf (11 Januari 2020).

Barreto, M. and Giantari, I.K., 2015. Strategi Pengembangan Objek Wisata Air Panas di Desa Marobo, Kabupaten Bobonaro, Timor Leste. E-Jurnal Ekonomi dan Bisnis Universitas Udayana, 4(11), 773-796.

Damanik, J., Rindrasih, E., Cemporaningsih, E., Marpaung, F., Raharjana, D.T. and Brahmantya, H., 2018. Membangun pariwisata dari bawah. UGM PRESS.

Erdiaw-Kwasie, M.O. and Acheampong, M.Y., 2018. Empowerment and community salience in multi-party collaboration: empirical lessons for development planning. Development in Practice, 28(7), 932-942.

Jalunggono, G., \& Destiningsih, R., (2018). Pemberdayaan Masyarakat Dan Dampak Ekonomi Pariwisata Di Desa Wisata Kutawaru Kabupaten Cilacap. Jurnal Rep (Riset Ekonomi Pembangunan), 3(2), 369-378.

Kamaru, B., Sambiran, S., \& Rondonuwu, A., 2017. Strategi Pemerintah Daerah dalam Mengembangkan Objek Wisata di Kabupaten Bolaang Mongondow Utara. Jurnal Eksekutif, 2(2), 1-10.

Kurniawan, F., 2013. Kemitraan Pengelolaan Sektor Pariwisata (Studi Pada Tirta Wisata Kabupaten Jombang). Jurnal Administrasi Publik, 1(1), 47-55.

Masruroh, R., dan Nurhayati, N. 2016. Strategi Pengembangan Pariwisata dalam Rangka Peningkatan Pendapatan Asli Daerah di Kabupaten Kuningan. In Prosiding Seminar Nasional IPTEK Terapan (SENIT) 2016 Pengembangan Sumber Daya Lokal Berbasis IPTEK, 1(1), 124-133.

Pebriani, N. K. D., Erviantono, T., \& Wismayanti, K. W. D., 2017. Kemitraan Pengembangan Sektor Pariwisata (Studi Kasus: Bali Elephant Camp, Desa Wisata Carangsari, Kecamatan Petang, Kabupaten Badung). Citizen Charter, 1(1), p.165251.

Pratiwi, H., 2017. Strategi Pemberdayaan Masyarakat Melalui Desa Wisata Mandiri Di Desa Wanurejo Kecamatan Borobudur Kabupaten Magelang (Doctoral dissertation, Universitas Negeri Semarang). Diakses dari: https://lib.unnes.ac.id/29722/ (11 Januari 2020).

Simamora, R. K., dan Sinaga, R. S., 2016. Peran Pemerintah Daerah dalam Pengembangan Pariwisata Alam dan 
Budaya di Kabupaten Tapanuli Utara. JPPUMA Jurnal Ilmu Pemerintahan dan Sosial Politik Universitas Medan Area, 4(1), 79-96.

Sugiyono. 2009. Metode Penelitian Bisnis. Penerbit Alfabeta. Bandung

Sukma, S. T. I. M., 2018. Pengaruh Promosi Dan Fasilitas Terhadap Jumlah Pengunjung Pada Museum Daerah Kabupaten Deli Serdang. Diakses dari: https://osf.io/ preprints/inarxiv/nuyf9/ (11 Januari 2020).
Suryatman, D., \& Setiowati, N. E., 2016. Pemberdayaan Ekonomi Masyarakat Manis Kidul Dalam Menunjang Pendidikan Formal Di Objek Wisata Cibulan Kecamatan Jalaksana Kabupaten Kuningan. Edueksos: Jurnal Pendidikan Sosial \& Ekonomi, 5(1), 55-63.

Terry, J., Mukti, A. and Sunaryati, R., 2020. Valuasi Ekonomi Objek Wisata Dermaga Kereng Bangkirai Sungai Sebangau Kota Palangka Raya. Journal of Environment and Management, 1(2), 83-90. 